\title{
Impact of Business Intelligence Solutions on Export Performance of Software Firms in Emerging Economies
}

\author{
Michael Neubert and Augustinus Van der Krogt
}

\author{
"We should keep on going along the path of" \\ globalization. Globalization is good... when \\ trade stops, war comes.
}

Jack Ma

Business magnate, investor, and philanthropist

Co-Founder of the Alibaba Group

\begin{abstract}
The article is written with the aim of understanding how well software firms in emerging economies perform when exporting their goods. Focusing on Paraguay as a representative context, a multiple-case-study research design was adopted using different sources of evidence, including 15 in-depth interviews with founders, shareholders, and CEOs. The data were analyzed using grounded theory in order to develop patterns and categories, and to understand differences and regularities. The revised Uppsala internationalization process model was used as a theoretical framework. This article highlights the experts' views of the impact of business intelligence on the export performance of software firms in Paraguay. Although only a few of the interviewees currently use business intelligence solutions to support international strategic decision-making processes, most of them reveal a desire to use them because they expect it will have a positive impact on export performance and international competitiveness. The main factors for selecting a business intelligence solution are transparency of cost and benefits, excellent client service, and an attractive pricing model. The study results apply to all stakeholders who support the impact of business intelligence systems on the export performance of software firms in emerging economies. The article fulfils an identified need and call for research to study the use and impact of business intelligence on the way an emerging country's exportation of goods actually performs, and the ability of its software firms to globalize successfully.
\end{abstract}

\section{Introduction}

Companies seeking to internationalize use business intelligence to create strategies and technologies for collecting and analyzing foreign market data and to predict the future attractiveness of new foreign markets (Dedić \& Stanier, 2016). Business intelligence helps to increase the speed of internationalization (Manyika et al., 2016) by gaining knowledge and creating networks in new foreign markets with limited resources, increasing efficient decision-making during market evaluation and finally, it helps to select the most attractive foreign markets (Autio \& Zander, 2016). More applications such as international pricing decisions (Neubert, 2017b) or acquiring domestic distributors might benefit from the use of business-intelligence systems.
In Paraguayan software businesses, as in other locales and industries, there is a great need to understand the extent to which business intelligence impacts the performance of their exports. Paraguay's open economy is home to innovative software firms (Neubert \& Van Der Krogt, 2017), and they need speed to aim their new products toward international markets, for example, to refinance their research and development cost (Neubert, 2016b). Thus, the Paraguayan software sector might enable future competitiveness by using business intelligence to develop international markets.

The goal of this study is to understand the use and impact expected by business intelligence on Paraguayan software exports and internationalization activities of firms. It follows on from research by Coviello, Kano, 


\section{Impact of Business Intelligence Solutions on Export Performance of Software Firms in Emerging Economies Michael Neubert and Augustinus Van der Krogt}

and Liesch (2017), Manyika and co-authors (2016), and Vahlne and Johanson (2017), and continues the research of Neubert and Van Der Krogt $(2017,2018)$. Their papers demonstrate a need for further research about the impact of business intelligence on internationalization. Vahlne and Johanson (2017) suggested that this need should be addressed through qualitative research methods such as multiple case studies. Due to the importance of early and fast internationalization (Neubert \& Van Der Krogt, 2017), the expected impact of business intelligence might be important for Paraguayan software firms as an example for high-tech firms from emerging markets (Neubert \& Van Der Krogt, 2017), which is the main motivation for this study. Our goal is to develop a market evaluation framework, and we outline the importance of business intelligence in the whole market development process including broader aspects in addition to those found in that of international entrepreneurship and business intelligence.

After the introduction, this article continues with a review of the existing and current literature about the Uppsala internationalization process model, which is the theoretical framework selected for this study (Vahlne \& Johanson, 2017). Then, it presents the research methodology including the sampling strategy and the research questions. Next, the research questions are answered based on the findings of this multiple-case study. Then, the results are discussed and compared with research results from other studies. Finally, the article concludes with a list of key findings, an analysis of the impact of the research results, and recommendations for further research.

\section{Literature Review and Theoretical Framework}

For 40 years, the Uppsala internationalization process model has been an important and heavily discussed theoretical framework (Håkanson \& Kappen, 2017) that describes the initial stages of internationalization (Neubert, 2015; Santangelo \& Meyer, 2017). During this time, Johanson and Vahlne have regularly adapted their theoretical framework to a changing international business environment and progress in research about internationalization (Johanson \& Vahlne, 2009; Vahlne \& Johanson, 2013, 2017). In this context, Coviello and colleagues (2017) called for further research to understand the impact of macro-level influences, including digitalization, on the Uppsala internationalization process model (Figure 1).

The Uppsala internationalization process model, as updated in 2017, consists of two change variables and two state variables (Figure 1) (Vahlne \& Johanson, 2017). The state variables are "capabilities" and "commitments/performance" (Vahlne \& Johanson, 2017). The change variables are "knowledge development processes" and "commitment processes" (Vahlne \& Johanson, 2017). The arrows show the relationship between change and state variables, for example, the dedication of additional resources to a foreign market or the acquisition of additional knowledge influences the firms' performance and its capabilities.

The framework of the "entrepreneurial knowledge development process" is used in this study because the

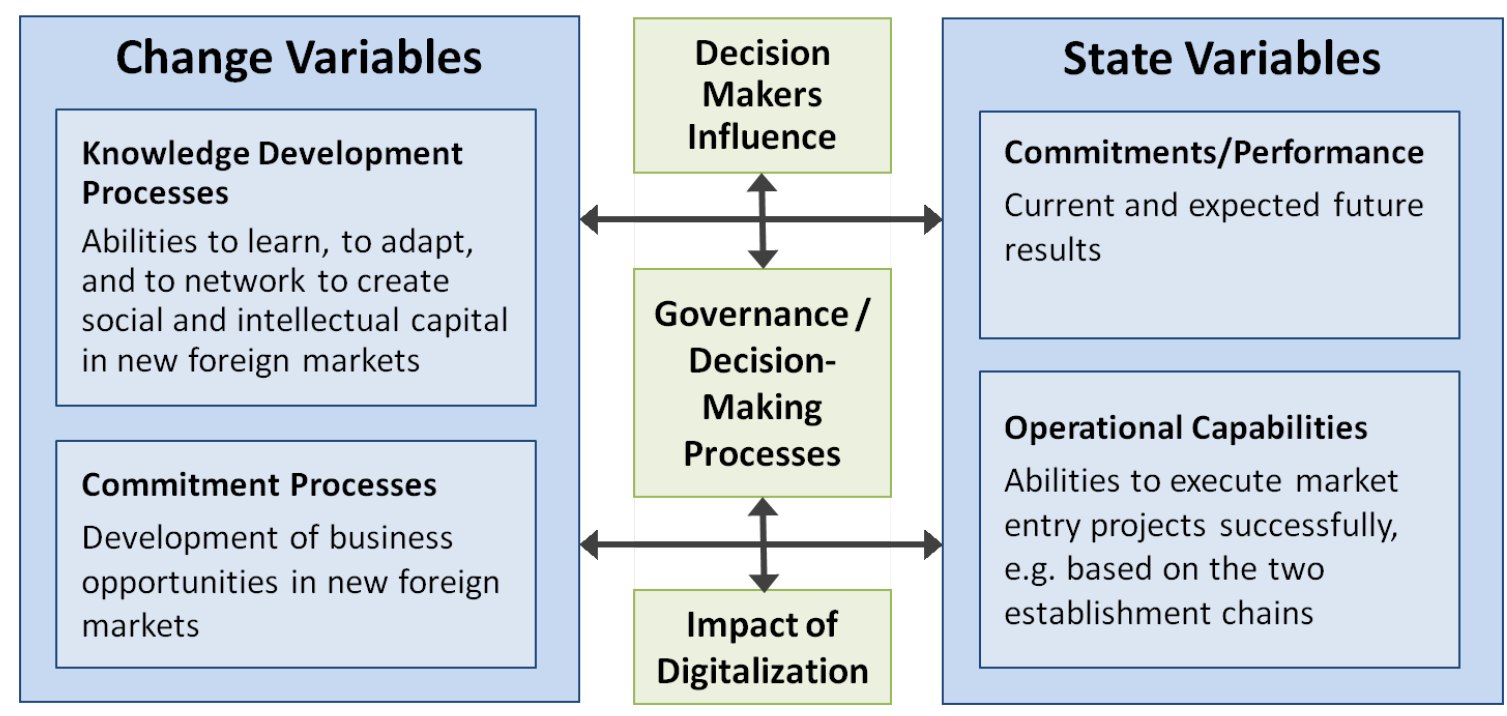

Figure 1. Theoretical framework based on the Uppsala internationalization process model (Vahlne \& Johanson, 2017; Coviello et al., 2017) 


\section{Impact of Business Intelligence Solutions on Export Performance of Software Firms in Emerging Economies Michael Neubert and Augustinus Van der Krogt}

Paraguayan software firms in this sample are entrepreneurial firms managed by their owners or founders. This process consists of three elements: 1) "relationship building" (e.g., creating business opportunities and building trust with new clients and distributors), 2) "strategic flexibility", and 3) "adaptability to the task environment" (Vahlne \& Johanson, 2017). The abilities to learn, to adapt (i.e., to create intellectual capital), and to network (i.e., to create social capital) support the development of market- and firm-specific advantages, which make market entries successful. The second change variable of the Uppsala internationalization process model is "commitment processes", which can also be defined as "opportunity development" (Vahlne \& Johanson, 2017) in foreign markets. This variable describes the identification, acquisition, and the development of business opportunities in new foreign markets.

Under the headline "operational capabilities", Vahlne and Johanson (2017) describe one of the most import elements of the Uppsala internationalization process model: "establishment chains" (Figure 2). High-tech firms, such as the software firms in our sample, use establishment chains to enter new foreign markets. As the first step in this internationalization process, Paraguayan software firms enter culturally and geographically closer markets such as Brazil, Bolivia, or Argentina with low-risk and low resource-consuming market-entry modes, such as "service export" or "software licensing", mostly in collaboration with domestic distributors
(Neubert \& Van Der Krogt, 2017; Neubert, 2017a). This process is called the market distance establishment chain (Figure 2).

With growing success, Paraguayan software firms might increase their presence in these markets, by establishing a wholly owned subsidiary, for example, or by acquiring their domestic distributor (Neubert, 2013b). This process is called the market commitment establishment chain (Figure 2). In parallel, such firms also might begin to enter more distant foreign markets such as Chile and Mexico, or they might follow their existing key account clients to even more distant markets. The attractiveness of foreign markets is often volatile. It might change quickly due to the acquisition of a new client or the loss of an established sales channel, also leading to outcomes such as a decreasing market commitment (Clarke \& Liesch, 2017) or even a market exit (Neubert, 2011, 2013a; Sapouna et al., 2018).

Other elements of Johanson and Vahlne's Uppsala internationalization process model are the liabilities of foreignness and outsidership (Vahlne \& Johanson, 2017). Paraguayan software firms, for example, need a bundle of sufficiently strong market- and firm-specific advantages to compensate for the liabilities of foreignness and outsidership (Vahlne \& Johanson, 2017). Among the main market- and firm-specific advantages of Paraguayan software firms are lower cost than American competitors and being in a similar time zone as

\begin{tabular}{|l|l|l|l|}
\hline \multirow{2}{*}{$\begin{array}{l}\text { Market Selection } \\
\text { and Distance }\end{array}$} & \multicolumn{1}{c|}{$\begin{array}{c}\text { Export } \\
\text { Direct Export } \\
\text { (With Distributor) }\end{array}$} & Sales Office & $\begin{array}{c}\text { Wholly-Owned } \\
\text { Subsidiary with } \\
\text { Local Production }\end{array}$ \\
\cline { 2 - 4 } $\begin{array}{l}\text { Mercosur Member States } \\
\text { (Argentina, Brazil, Paraguay, } \\
\text { Uruguay, and Venezuela) }\end{array}$ & & $\begin{array}{l}\text { Market Commitment } \\
\text { Establishment Chain }\end{array}$ & \\
\hline $\begin{array}{l}\text { Other Foreign Markets } \\
\text { in Latin America }\end{array}$ & & & \\
\hline $\begin{array}{l}\text { Other Foreign Markets with } \\
\text { Spanish-Speaking Communities }\end{array}$ & $\begin{array}{l}\text { Market Distance } \\
\text { Establishment Chain }\end{array}$ & & \\
\hline & & & \\
\hline
\end{tabular}

Figure 2. Market distance and market commitment establishment chain 


\section{Impact of Business Intelligence Solutions on Export Performance of Software Firms in Emerging Economies Michael Neubert and Augustinus Van der Krogt}

American clients, relative to competitors from other lowcost countries such as India. In particular, the advantage of being able to communicate with clients in the United States during normal office hours and in the same language and similar culture should not be underestimated, because it is greatly appreciated by American clients.

The larger the economic, linguistic, geographical, administrative, and cultural distances (Ghemawat, 2007) between the foreign target market and the home market, the larger the liabilities of outsidership and foreignness, and the larger the need for firm-specific competitive advantages (Vahlne \& Johanson, 2017). All software firms and their employees have something like a global industry culture because they share the same technical language, tools (e.g., software), and methodologies (e.g., agile programming). This familiarity with the same technologies, methodologies, and language reduces the liabilities of foreignness and outsidership.

Domestic distributors help Paraguayan software firms to bridge these distances. They might help them to adapt their product features, pricing, marketing communication, or terms of doing business (e.g., payment conditions and warranties) (Deresky, 2017; Hollensen, 2017). In addition, they might offer services related to importing, legal and compliance advice, logistics (including storage), client acquisition and service, and accounts receivable management (Neubert, 2016a, 2017a). Distributors provide market knowledge and access to domestic client networks immediately, which increases the speed of market entry in comparison to a hierarchical mode of market entry. Thus, the speed of internationalization depends on the speed of knowledge and network creation (Vahlne \& Johanson, 2017; Neubert, 2017a; 2016b) in each new foreign market, preferably with the support of a local partner. Despite all the services distributors provide, digitalization might lead to disintermediation using online marketing or distribution channels such as social media.

The Uppsala internationalization process model was also chosen as the theoretical framework of this study because it has already been adopted by many Paraguayan software firms in this sample to develop neighbouring foreign markets (Neubert \& Van Der Krogt, 2017). Although the export volume of Paraguayan software firms is still very low (Trade Map, 2018), they consider speedy internationalization as important for the long-term survival of their firms due to the limited size of their domestic home market (Neubert \& Van Der Krogt, 2017). However, they often are confronted with significant delays in the execution of their international market development activities in comparison to the time planned in their business plans (Neubert \& Van Der Krogt, 2017). The main reason is an often unplanned and unstructured internationalization behaviour (Neubert \& Van Der Krogt, 2017). Paraguayan software firms often enter new foreign markets based on their existing networks and clients by using market opportunities, or by following existing clients without analyzing the appeal of new foreign markets in detail (Neubert \& Van Der Krogt, 2017). Founders, shareholders, and CEOs understand that this reduces the speed of international market development. Previously, we have seen that they acknowledge the importance of a structured market-development process (Figure 3) starting from a detailed evaluation and selection of foreign markets before they actually enter them (Neubert \& Van Der Krogt, 2017). Founders, shareholders, and CEOs recognize that their capabilities and their firms' capabilities are crucial for their international success. The faster they learn how to do business and to acquire customers in new foreign markets, the higher the speed of internationalization (Neubert \& Van Der Krogt, 2017; Vahlne \& Johanson, 2017). However, this learning is especially challenging for Paraguayan software firms, because they internationalize from an emerging to a generally higher developed market (Buckley et al., 2017).

This multiple-case study uses Gartner's (2018) definition of digitalization, which is "the use of digital technologies to change a business model" or business processes. The aim of digitalization is the integration of digital technologies (Gray \& Rumpe, 2015; Khan, 2016) into core processes such as the foreign market development process of Neubert $(2011,2013 b)$. Due to the digitalization of foreign market evaluation and selection processes (Figure 3), Paraguayan software firms might collect, store, and analyze social data (market networks)

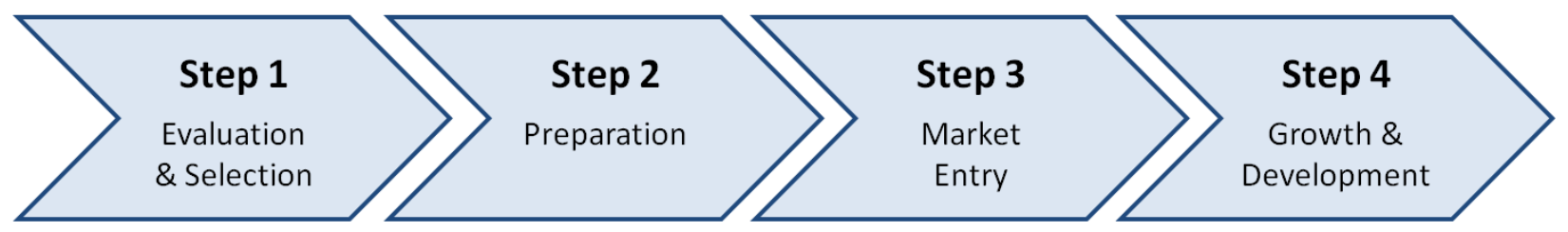

Figure 3. Foreign market development process (Adapted from Neubert, 2017a) 


\section{Impact of Business Intelligence Solutions on Export Performance of Software Firms in Emerging Economies Michael Neubert and Augustinus Van der Krogt}

and intellectual data (market knowledge) about foreign markets faster than with other methods (Coviello et al., 2017; Vahlne \& Johanson, 2017).

Digitalization improves decision-making processes and the ability of decision makers to decide effectively (Clark et al., 2018; Neubert, 2018). Decisions relating to market-entry strategies or market-entry modes can be particularly challenging (Ahi et al., 2017): their preparation requires significant resources to analyze data, to predict outcomes, and to develop alternative solutions. Therefore, digitalization increases the effectiveness and reduces the manual work of these decision-support processes (Holsapple et al., 2014; Merkert et al., 2015).

Traditional data-driven and fact-based decision-making processes increase the productivity and profitability of companies by five to six per cent compared to their competitors (Bohanec et al., 2017; Neubert, 2018). Companies using prescriptive, analytics-based, machinelearning (ML) algorithms, for example, to compute the future attractiveness of international markets or to identify new business opportunities (Dedić \& Stanier, 2016; Neubert, 2017a; Witten et al., 2016) increase their revenues by more than $15 \%$ (Kawas et al., 2013). However, such gains are only possible if international managers understand and are able to leverage the benefits of digitalization (Ransbotham et al., 2015).

\section{Methodology and Research Questions}

The purpose of this study has brought up the following three research questions:

1. Are Paraguayan software firms using business intelligence solutions to support international strategic decision-making processes?

2. What is the perceived impact of business intelligence solutions on export performance and internationalization?

3. What factors determine the use and the selection of business intelligence services?

This study uses a multiple-case-study research design to provide answers to these descriptive and explanatory research questions (Yin, 2017). In contrast to an experimental design or a survey, a multiple-case-study method is more flexible, and it allows for an in-depth analysis of this research problem (Yin, 2017) within a highly-contextualized environment (e.g., export) also al- lowing for a comparison between the different cases presented. This research design helps answer the research questions because it allows the use of the replication logic so as to receive external and internal validities and analyze pattern-matching properties between theories and cases (Yin, 2017).

We used the triangulation concept during the data collection phase of this study to ensure that different sources of evidence were used to collect data from each case, the reason being that this study used various sources of evidence to derive sound conclusions and to achieve construct validity. The primary source for data collection comprised qualitative, semi-structured, indepth, individual face-to-face interviews with subjectmatter experts who were all founders, shareholders, or CEOs of Paraguayan software firms with significant international management experience and higher education. Only one person per case study firm was interviewed. The software firms focus on the development of products and services for niche markets, which can compete at a domestic and foreign market level (Neubert \& Van Der Krogt, 2017). Other sources used were: firm and product flyers and brochures, corporate websites, and internal documents provided by the interviewees and other secondary data, which were collected in October and November 2017. The reliability criteria were met by using the same questionnaire, study protocol, and data structure in the data collection phase. The questionnaire consisted of nine explorative, open-ended questions, which were found to be easy to understand and to digest with no further need for clarification. The average duration of the interviews was 90 minutes.

The data analysis followed a logical sequence, starting with an individual analysis of each interview, which in turn was followed by a cross-comparison of the results to identify differences and similarities between the answers of the different interviewees, a theoretical and literal replication using a pattern-matching approach, and finally a comparison with the research findings similar studies (Neubert, 2018). The main goal of this approach is to increase the possibility to transfer and generalize the findings to other contexts (Yin, 2017).

The sampling was based on a purposive case-selection strategy. After drawing a random sample from a database of 60 Paraguayan firms, which are active in the software services sector (Fernandez \& van der Krogt, 2015), 15 typical cases of the sample exporting software products were selected. According to Yin (2017), if at 


\section{Impact of Business Intelligence Solutions on Export Performance of Software Firms in Emerging Economies Michael Neubert and Augustinus Van der Krogt}

least six to ten cases are selected, this sampling strategy produces a statistically representative sample. Data saturation was achieved with 15 interviews due to repetitive answers. This sample size is higher than required, which allows for a better triangulation of data and helps to strengthen the results of the whole study (Yin, 2017).

\section{Research Findings}

The analysis of the data collected from the in-depth, semi-structured, qualitative, face-to-face interviews with founders, shareholders, and CEOs of Paraguayan software firms revealed themes that answer each of the three research questions, as described in the subsections below.

1. Are Paraguayan software firms using business intelligence solutions to support international strategic decision-making processes?

Theme 1: Paraguayan founders, shareholders, and CEOs and their software firms currently do not use business intelligence solutions, in terms of big data and predictive analytics, to support international strategic decision-making processes.

Only one (7\%) of the interviewees is using theories of internationalization, country market data, and analytics in the form of predictions, which appear as market studies to evaluate the attractiveness of foreign markets. According to the interviewees, the limited use of big data and this type of analytics in strategic decisionmaking can be explained during the initial stages of business intelligence in Paraguay as an emerging economy. At this moment, business intelligence strategies are still confined to the few larger - multinational companies in the telecommunications and financial sector. Moreover, although macroeconomic data are mostly available, there are very limited sector-specific data in industry and services sectors in Paraguay, and this is a topic brought up by most of the interviewees. The perception of the interviewees about limited sectorspecific data in Paraguay and in foreign markets should rather be interpreted in the sense that Paraguayan founders, shareholders, or CEOs currently have no access to this data for various reasons. The majority of the interviewees mentioned that this is further complicated by a lack of data analysis knowledge and experience in their interpretation. Business intelligence and especially big data analytics is therefore still at a premature stage and is difficult to use to support business objectives in Paraguay.
Theme 2: Paraguayan founders, shareholders, and CEOs generally do not use business intelligence solutions to analyze the attractiveness of new markets due to insufficient experience and knowledge.

Despite the more advanced availability of macro-economic and sector-specific data in other countries such as Brazil and Mexico as well as developed countries, the situation in Paraguay affects the knowledge, experience, and expectations of data usage for internationalization in industry and services. In the specific case of the software sector, the study shows us that less than half the companies have sufficient knowledge $(40 \%)$ and experience (35\%) to make effective use of business intelligence in general, and predictive data in particular. At this point, among the Paraguayan software firms, only one company is using predictive data to identify foreign market opportunities, including the prediction of market appeal or client development. Other companies indicate that the limited use of data is partially explained by a lack of time to study and apply it. Therefore, effective use of predictive data would require companies to grant more time and training resources.

The main finding of the first research question is that only a minority of founders, shareholders, or CEOs and their software firms use business intelligence solutions at the moment, in terms of big data and predictive analytics, to support international strategic decision-making processes such as foreign market evaluation and selection or the acquisition of new clients due to a missing experience and knowledge about these tools. These findings support the results of Neubert (2018).

\section{What is the perceived impact of business intelligence solutions on export performance and internationaliza- tion?}

Theme 3: The majority of Paraguayan founders, shareholders, and CEOs are interested in using business intelligence solutions, in terms of big data and predictive analytics, to support international strategic decisionmaking processes.

Despite what is currently known and experienced, nine (70\%) of the interviewees are interested in using business intelligence when dealing with big data and predictive analytics to support their internationalization strategy in the short term. Eleven (85\%) of the interviewees can see themselves using business intelligence in terms of big data and predictive analytics in the long term because they are in the process of identifying new 


\section{Impact of Business Intelligence Solutions on Export Performance of Software Firms in Emerging Economies Michael Neubert and Augustinus Van der Krogt}

foreign market opportunities, and they want better insights into the market potential. However, it is important to observe that the interviews also reveal that actually acquiring and using predictive data may be rather difficult due to time constraints and little willingness to pay for data services, which is also combined with high expectations of data sets being flexible and integral to their needs.

Theme 4: The majority of Paraguayan founders, shareholders, and CEOs are interested in using business intelligence solutions, in terms of big data and predictive analytics, to support international strategic decisionmaking processes due to their expected positive impacts.

The research provides some hints about the perceived short-term impact of business intelligence in terms of big data and predictive analytics on sales. In the short term, the interviewees indicate that predictive data can assist mainly in identifying new markets, market segments, leads, and clients. It can also help in better and faster planning, better-informed decision-making, and greater control of sales. To a lesser extent, the data are thought to be useful to the founders, shareholders, or CEOs choosing sales channels and optimizing their sales funnel as well as in terms of big data and predictive analytics, which in any case are less effective when it comes to increasing loyalty and sales volume of the existing clients.

The interviewees expect an even stronger long-term impact on productivity and profitability of international operations. About $77 \%$ can foresee more than a six per cent increase in profitability and growth and $54 \%$ of the interviewees indicate more than a six per cent increase in productivity. As much as $85 \%$ expect these improvements because of a more optimistic forecast concerning the service needs of existing clients. A large majority of the participating companies also indicate the potential of contribution by clearer calculations of the attractiveness of foreign markets, predictions of market developments in specific subsectors, and the reduction of risks in the market. The companies have lower expectations with regards to the contribution to cost reductions, forecasting of revenues, price developments, and competition. A majority (62\%) of the interviewees expected an improved sales process in terms of improved efficiency during sales negotiations, faster and better decision making, and a reduction of sales risks. Almost half of the interviewees can imagine that business intelligence in terms of big data and predictive analytics will contribute to an increased turnover per client, an improved relationship with clients, and more motivated salespeople.

The main finding relating to the second research question is that the majority of founders, shareholders, and CEOs want to use business intelligence in terms of big data and predictive analytics as they believe that their export performance and on their competitiveness in international market development is impacted positively. This belief of the interviewees is supported by the current literature. According to Bohanec colleagues (2017) and Kawas and colleagues (2013), the use of business intelligence positively influences revenues, productivity, and profitability.

\section{What factors determine the use and the selection of business intelligence services?}

Theme 5: The main factors that determine the use and the selection of business intelligence services in terms of big data and predictive analytics are transparency of cost and benefits and an excellent after-sales service.

When considering the use of a business-intelligence service in terms of big data and predictive analytics, the founders, shareholders, and CEOs are restrained in making their decision by a variety of assumptions. The interviewees expressed concern about a lack of support in the make-up of data as well as its unclear selection, processing, and evaluation (i.e., the "black box effect") and they further assume that the cost of data services is inflated in relation to the small size of their business. The interviewees also consider the benefits of the software solution to be unclear and have a lack of comprehension as to its specific relevance. Furthermore, they perceive a lack of motivation of the clients and distributors to collaborate in the use of predictive data. This call for transparency mainly shows that Paraguayan founders, shareholders, and CEOs have limited experience and knowledge with big data and predictive analytics software to support strategic decision making because they are unsure about trusting and basing their decisions on the results presented. Contrary to what could be expected, few founders, shareholders, and CEOs are worried about the management of the software and training of employees.

To select a business-intelligence platform to support internationalization, the founders, shareholders, and CEOs will mainly consider a business-intelligence solution that responds to the expected problems mentioned 


\section{Impact of Business Intelligence Solutions on Export Performance of Software Firms in Emerging Economies Michael Neubert and Augustinus Van der Krogt}

earlier. Over $85 \%$ of the interviewees would choose based on an excellent after-sales client service that accompanies the company in the use of the service. The interviewees will instead consider recommendations and references by existing clients. They further expect a low price that reflects the relatively small size of their own business, along with a high level of flexibility and integrality. Few interviewees are concerned about the size and reputation of the provider that offers additional services, such as supplying them with professional training and consulting.

The main finding of the third research question is that the leading factors that determine the use and the selection of business intelligence services are transparency of cost and benefits. Further, founders, shareholders, and CEOs expect an excellent client service and an attractive pricing model.

\section{Discussion}

This is based on a call for research made by Coviello and colleagues (2017) and Vahlne and Johanson (2017), and it continues the research of Neubert and Van Der Krogt $(2017,2018)$ and Neubert (2018) about the impact of digitalization in the sense of business intelligence solutions on internationalization. Therefore we discuss the findings of this multiple-case study in comparison to the findings of the existing relevant literature. The main motivation and assumption of this study is that business intelligence might increase the efficiency of internationalization. The findings are discussed along the three dimensions: knowledge and experience, decisionmaking criteria, and expected impact on performance (Figure 4).

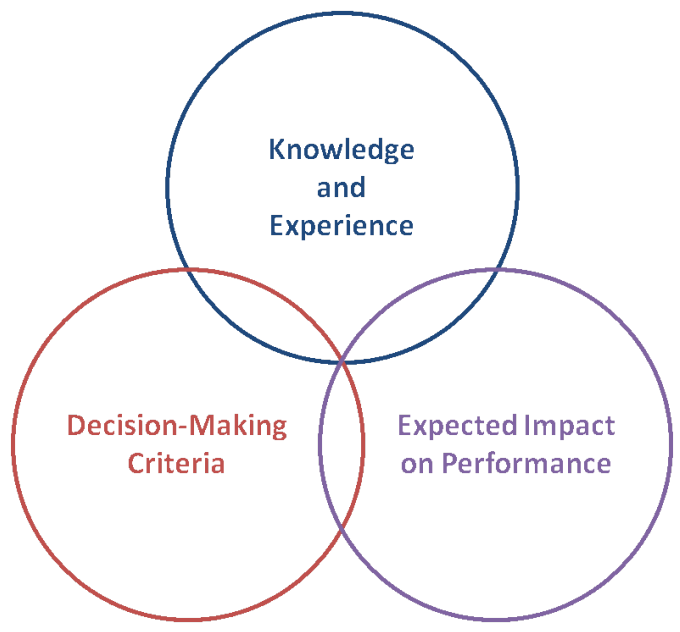

Figure 4. The three dimensions of the discussion framework
The goal of the first research question is to understand the perceptions of founders, shareholders, and CEOs of software firms about the use of business intelligence. The findings suggest that the interviewees and their software firms still lack knowledge and experience about the application of business intelligence solutions to support international decision-making processes. The study of Neubert (2018) produced similar results. Although both studies are qualitative and therefore hardly generalizable, the findings of both of them suggest that there is probably a substantial need for training and consulting. Founders, shareholders, and CEOs need specific use cases about the evaluation and selection of new foreign markets to understand the benefits of digitalization. This happens in this fast-changing environment with huge amounts of data as well as significant risks and long-term financial commitments. It is the almost perfect environment for business intelligence solutions in terms of big data and predictive analytics to support international strategic decision-making processes of entrepreneurs with limited resources.

The goal of the second research question is to understand the opinions of subject-matter experts regarding the expected impact of business intelligence on export performance and internationalization. The findings suggest that the majority of the interviewees want to use business intelligence solutions due to its perceived positive impact on performance. The lack of data and the missing experience and knowledge about business intelligence solutions are the barriers to usage. This belief of the interviewees is supported by the current literature. According to various authors (Bohanec et al., 2017; Kawas et al., 2013); Müller et al., 2018; Neubert, 2018), the use of business intelligence solutions that leverage artificial intelligence provides a significant impact of around $15 \%$ on revenues, productivity, and profitability, especially due to a higher efficiency of international learning (Stoian et al., 2017) and networking activities (Coviello et al., 2017; Vahlne \& Johanson, 2017). According to Neubert (2018), the most important needs for digitalization are lead generation, client acquisition, and client retention.

The goal of the third research question is to understand the views of founders, shareholders, and CEOs about the factors that determine the use and the selection of business intelligence solutions. The suggested findings demonstrate that transparency of cost and benefits, as well as good client service and attractive prices are the main factors that determine the use and the selection of business intelligence. The findings of Neubert (2018) 


\section{Impact of Business Intelligence Solutions on Export Performance of Software Firms in Emerging Economies Michael Neubert and Augustinus Van der Krogt}

confirm the criteria transparency of cost, benefits, and attractive price-performance ratios in addition to the following factors: transparency about data protection (including collection and analysis) and the ability to integrate the business intelligence solution into existing enterprise resource planning (ERP) systems. Finally, founders, shareholders, and CEOs want to avoid the "black box effect", meaning they want to understand the algorithms to the extent that they can put trust in the results.

The discussion of the findings and their comparison with the existent literature shows that there is high interest as well as high expectations but relatively low experience and knowledge among the interviewees concerning the impact of business intelligence solutions, in the sense of big data and predictive analytics, on export performance of Paraguayan software firms.

\section{Conclusions}

This article fulfils a need that has been observed for research to study the use and the expected impact of business intelligence solutions on export performance and international competitiveness of software firms, especially those in emerging economies. The findings bring to light additional insights about the impact of business intelligence on the export performance of Paraguayan software firms using the Uppsala internationalization process model as a theoretical framework.

The first finding of this study is that only a few of the Paraguayan software firms in this sample currently use business intelligence solutions in terms of big data and predictive analytics to support their international strategic decision-making processes, such as the evaluation and selection of foreign markets, due to a lack of data as well as insufficient experience and knowledge.

The second finding of this study is that the majority of founders, shareholders, and CEOs would like to use business intelligence solutions in terms of big data and predictive analytics because they expect a significant positive impact on export performance and on their competitiveness in international market development.
The third finding of this study is that the principal factors that determine the use and the selection of business intelligence services are transparency of cost and benefits. Further, founders, shareholders, and CEOs expect excellent client service and an appealing pricing model. The call for more transparency is mainly based on the interviewees doubting whether they can trust the results and whether it makes sense to base their decisions on them in addition to (or perhaps in opposition to) their own experience and intuition.

The results are relevant for many people dealing with internationalization, including export promotion agencies, researchers in international entrepreneurship, and developers of predictive analytics software, who support the kind of activities that promote engaging with the development, training, and application of business intelligence systems or in general digitalization for international decision making. The reason for this is better understanding of the impact of business intelligence on the export performance and internationalization, especially among software firms in emerging economies. The results are particularly relevant for the future competitiveness of the entire Paraguayan software sector and should motivate all stakeholders to monitor and continue this research stream.

The qualitative multiple-case-study research design limits the generalizability of the findings but suggests areas for additional research. Qualitative research is based more on the perceptions, views, and opinions of subject-matter experts rather than the actual measurement of results. Thus, qualitative studies are unique and therefore difficult to replicate. Therefore, future scholarly work should include quantitative assessments and data of the perceptions of subject-matter experts in Paraguay and elsewhere to come to solid conclusions and to provide greater clarification as to the statistical significance of the variables presented in this study, so as to manage to replicate the results of other software firms from different emerging or developed country markets. 


\section{Impact of Business Intelligence Solutions on Export Performance of Software Firms in Emerging Economies Michael Neubert and Augustinus Van der Krogt}

\section{About the Authors}

Michael Neubert is a Professor at the International School of Management in Paris, France, where he obtained his $\mathrm{PhD}$ and is now also Chair of the Strategic Management Committee. He teaches international business, intercultural communication, doing business in foreign markets, and international finance. His research interests concern the internationalization of high-tech startups. Michael is a member of the Academy of International Business, and he is a partner of a private equity firm that invests in hightech startups and supports them in the development of new foreign markets. Michael is also the CEO of C2NM (www.c2nm.com), a Swiss consulting firm specializing in the field of international and intercultural management.

Augustinus (Stijn) Van Der Krogt is the Dean of the Faculty of Business Administration at the Universidad Paraguayo Alemana in San Lorenzo, Paraguay. He is also a Director of the consulting firm Changing Values International, which accompanies private and public organizations in their process of change by providing tailor-made strategic advice and executive training and coaching.

\section{References}

Ahi, A., Baronchelli, G., Kuivalainen, O., \& Piantoni, M. 2017. International Market Entry: How Do Small and Medium-Sized Enterprises Make Decisions? Journal of International Marketing, 25(1): 1-21.

https://doi.org/10.1509/jim.15.0130

Autio, A., \& Zander, I. 2016. Lean Internationalization. Academy of Management Proceedings, 2016(1): 17420.

https://doi.org/10.5465/ambpp.2016.81

Bohanec, M., Borštnar, M. K., \& Robnik-Šikonja, M. 2017. Explaining Machine Learning Models in Sales Predictions. Expert Systems with Applications, 71(1): 416-428.

https://doi.org/10.1016/j.eswa.2016.11.010

Buckley, P. J., Doh, J. P., \& Benischke, M. H. 2017. Towards a Renaissance in International Business Research? Big Questions, Grand Challenges, and the Future of IB Scholarship. Journal of International Business Studies, 48(9): 1045-1064. https://doi.org./10.1057/s41267-017-0102-z

Clark, D. R., Li, D., \& Shepherd, D. A. 2018. Country Familiarity in the Initial Stage of Foreign Market Selection. Journal of International Business Studies, 49(4): 442-472.

https://doi.org/10.1057/s41267-017-0099-3
Clarke, J. E., \& Liesch, P. W. 2017. Wait-and-See Strategy: Risk Management in the Internationalization Process Model. Journal of International Business Studies, 48(8): 923-940. https://doi.org/10.1057/s41267-017-0110-z

Coviello, N., Kano, L., \& Liesch, P. W. 2017. Adapting the Uppsala Model to a Modern World: Macro-Context and Microfoundations. Journal of International Business Studies, 48(9): 1151-1164. https://doi.org/10.1057/s41267-017-0120-x

Dedić, N., \& Stanier, C. 2016. Measuring the Success of Changes to Existing Business Intelligence Solutions to Improve Business Intelligence Reporting. In A. Tjoa, L. Xu, M. Raffai, \& N. Novak (Eds), Research and Practical Issues of Enterprise Information Systems. CONFENIS 2016. Lecture Notes in Business Information Processing, Vol. 268. Cham, Switzerland: Springer.

Deresky, H. 2017. International Management: Managing Across Borders and Cultures (9th Ed.). London: Pearson Education.

Fernandez, L., \& van der Krogt, A. 2015. Estudio de mercado del uso de las Tecnologías de Información y Comunicación en el Paraguay. Asuncion, Paraguay: Universidad Paraguayo Alemana (UPA). http://www.upa.edu.py/wp-content/uploads/2016/07/Tics.pdf

Gartner. 2018. IT Glossary: Digitalization. Gartner. Accessed July 16, 2018:

https://www.gartner.com/it-glossary/digitalization

Ghemawat, P. 2007. Redefining Global Strategy: Crossing Borders in a World Where Differences Still Matter. Boston, MA: Harvard Business Press.

Gray, J., \& Rumpe, B. 2015. Models for Digitalization. Software \& Systems Modeling, 14(4): 1319-1320.

https://doi.org/10.1007/s10270-015-0494-9

Håkanson, L., \& Kappen, P. 2017. The 'Casino Model' of Internationalization: An Alternative Uppsala Paradigm. Journal of International Business Studies, 48(9): 1103-1113.

https://doi.org/10.1057/s41267-017-0113-9

Hollensen, S. 2017. Global Marketing (7th Ed.). London: Pearson Education.

Holsapple, C., Lee-Post, A., \& Pakath, R. 2014. A Unified Foundation for Business Analytics. Decision Support Systems, 64: 130-141. https://doi.org/10.1016/j.dss.2014.05.013

Johanson, J., \& Valhne, J. E. 2009. The Uppsala Internationalization Process Model Revisited: From Liability of Foreignness to Liability of Outsidership. Journal of International Business Studies, 40(9): 1411-1431. http://dx.doi.org/10.1057/jibs.2009.24

Kawas, B., Squillante, M. S., Subramanian, D., \& Varshney, K. R. 2013. Prescriptive Analytics for Allocating Sales Teams to Opportunities. In Proceedings of the 13th IEEE International Conference on Data Mining Workshops (ICDMW): 211-218. Piscataway, NJ: IEEE. https://doi.org/10.1109/ICDMW.2013.156

Khan, S. 2016. Leadership in the Digital Age: A Study on the Effects of Digitalization on Top Management Leadership. Dissertation. Stockholm: Stockholm University.

http://urn.kb.se/resolve?urn=urn:nbn:se:su:diva-133809

Manyika, J., Lund, S., Bughin, J., Woetzel, J., Stamenov, K., \& Dhingra, D. 2016. Digital Globalization: The New Era of Global Flows. New York: McKinsey Global Institute.

http://www.mckinsey.com/business-functions/digitalmckinsey/our-insights/digital-globalization-the-new-era-ofglobal-flows 


\section{Impact of Business Intelligence Solutions on Export Performance of Software Firms in Emerging Economies Michael Neubert and Augustinus Van der Krogt}

Merkert, J., Mueller, M., \& Hubl, M. 2015. A Survey of the Application of Machine Learning in Decision Support Systems. ECIS Completed Research Papers, Paper 133. https://doi.org/10.18151/7217429

Müller, O., Fay, M., \& vom Brocke, J. 2018. The Effect of Big Data and Analytics on Firm Performance: An Econometric Analysis Considering Industry Characteristics. Journal of Management Information Systems, 35(2): 488-509. https://doi.org/10.1080/07421222.2018.1451955

Neubert, M. 2011. Internationale Markterschließung: Vier Schritte zum Aufbau neuer Auslandsmärkte. München: MI Wirtschaftsbuch.

Neubert, M. 2013a. Global Market Strategies: How to Turn your Company in a Successful International Enterprise. Frankfurt: Campus Verlag.

Neubert, M. 2013b. Globale Marktstrategien: Das Handbuch für risikofreie Internationalisierung. Frankfurt: Campus Verlag.

Neubert, M. 2015. Early Internationalisation of High-Tech Firms: Past Accomplishments and Future Directions. International Journal of Teaching and Case Studies, 6(4): 353-369. https://doi.org/10.1504/IJTCS.2015.074603

Neubert, M. 2016a. Significance of the Speed of Internationalisation for Born Global Firms - A Multiple Case Study Approach. International Journal of Teaching and Case Studies, 7(1): 66-81. https://doi.org/10.1504/IJTCS.2016.076067

Neubert, M. 2016b. How and Why Born Global Firms Differ in Their Speed of Internationalization - A Multiple Case Study Approach International Journal of Teaching and Case Studies, 7(2): 118-134. https://doi.org/10.1504/IJTCS.2016.078168

Neubert, M. 2017a. Lean Internationalization: How to Globalize Early and Fast in a Small Economy. Technology Innovation Management Review, 7(5): 16-22.

http://timreview.ca/article/1073

Neubert, M. 2017b. International Pricing Strategies for Born-Global Firms. Central European Business Review, 6(3): 41-50. https://doi.org/10.18267/j.cebr.185

Neubert, M. 2018. The Impact of Digitalization on the Speed of Internationalization of Lean Global Startups. Technology Innovation Management Review, 8(5): 44-54. http://doi.org/10.22215/timreview/1158

Neubert, M., \& Van Der Krogt, A. 2017. Lean Internationalisation of High-Tech Firms. International Journal of Teaching and Case Studies, 8(2/3): 133-150. https://doi.org/10.1504/IJTCS.2017.086679

Neubert, M., \& Van Der Krogt, A. 2018. Impact of Business Intelligence on Export of Software Firms. Paper presented at the Innovation Management, Entrepreneurship and Sustainability (IMES 2018) Conference: 776-786. Prague. http://doi.org/10.18267/pr.2018.dvo.2274.0
Ransbotham, S., Kiron, D., \& Prentice, P. K. 2015. Minding the Analytics Gap. MIT Sloan Management Review, 56(3): 63-68.

Santangelo, G. D., \& Meyer, K. E. 2017. Internationalization as an Evolutionary Process. Journal of International Business Studies, 48(9): 1114-1130.

https://doi.org/10.1057/s41267-017-0119-3

Sapouna, P., Dimitratos, P., Larimo, J., \& Zucchella, A. 2018. Market Withdrawal, International Orientation and International Marketing: Effects on SME Performance in Foreign Markets. In L. Leonidou, C. Katsikeas, S. Samiee, \& B. Aykol (Eds.), Advances in Global Marketing: 281-303. Cham, Switzerland: Springer. https://doi.org/10.1007/978-3-319-61385-7_12

Stoian, M. C., Rialp, J., \& Dimitratos, P. 2017. SME Networks and International Performance: Unveiling the Significance of Foreign Market Entry Mode. Journal of Small Business Management, 55(1): 128-148. https://doi.org/10.1111/jsbm.12241

Trade Map. 2018. Paraguayan Export Volume of Telecommunications, Computer, and Information Services. International Trade Centre: Trade Map. Accessed September 15, 2018:

https://www.trademap.org/Country_SelServiceCountry_TS.aspx?n vpm $=1|600||||||S 09| 1|3| 1|2| 2|1| 2|1| 1$

Vahlne, J. E., \& Johanson, J. 2013. The Uppsala Model on Evolution of the Multinational Business Enterprise: From Internalization to Coordination of Networks. International Marketing Review, 30(3): 189-210. https://doi.org/10.1108/02651331311321963

Vahlne, J. E., \& Johanson, J. 2017. From Internationalization to Evolution: The Uppsala Model at 40 years. Journal of International Business Studies, 48(9): 1087-1102. https://doi.org/10.1057/s41267-017-0107-7

Witten, I. H., Frank, E., Hall, M. A., \& Pal, C. J. 2016. Data Mining: Practical Machine Learning Tools and Techniques. Cambridge, MA: Morgan Kaufmann.

Yin, R. K. 2015. Qualitative Research from Start to Finish. New York: Guilford Publications.

Citation: Neubert, M., \& Van der Krogt, A. 2018. Impact of Business Intelligence Solutions on Export

(cc) BY

Performance of Software Firms in Emerging Economies. Technology Innovation Management Review, 8(9): 39-49. http://doi.org/10.22215/timreview/1185

Keywords: international business, international management, international entrepreneurship, global marketing, emerging markets, business intelligence, machine learning, artificial intelligence, Paraguay, software industry 


\section{Academic Affiliations and Funding Acknowledgements}

Canadà
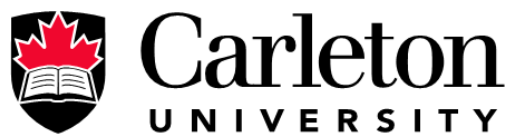

U N I V E R S I T Y

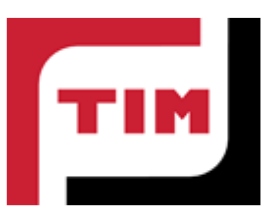

The Federal Economic Development Agency for Southern Ontario (FedDev Ontario; feddevontario.gc.ca) is part of the Innovation, Science and Economic Development portfolio and one of six regional development agencies, each of which helps to address key economic challenges by providing regionallytailored programs, services, knowledge and expertise.

- The TIM Review receives partial funding from FedDev Ontario's Investing in Regional Diversification initiative.

Technology Innovation Management (TIM; timprogram.ca) is an international master's level program at Carleton University in Ottawa, Canada. It leads to a Master of Applied Science (M.A.Sc.) degree, a Master of Engineering (M.Eng.) degree, or a Master of Entrepreneurship (M.Ent.) degree. The objective of this program is to train aspiring entrepreneurs on creating wealth at the early stages of company or opportunity lifecycles.

- The TIM Review is published in association with and receives partial funding from the TIM program. 